\title{
Population dynamics of exploited cultures of calanoid copepods*
}

\author{
D. R. Heinle \\ University of Maryland \\ Natural Resources Institute, Chesapeake Biological Laboratory; \\ Solomons, Maryland, USA
}

\begin{abstract}
A.BSTRACT: Dynamismes de la population des copépodes calanoides dans les cultures exploitées. En laboratoire, cultures des copépodes calanoides, Acartia tonsa (DANA) et Eurytemora affinis (POPPE) étaient exposées à différents taux de déprédation, allant de 10 à $24 \%$ des populations par jour, suivant les espèces et les températures. Les densités des populations variaient considérablement, ce qui provenait probablement des évènements intermittents (la nourriture et les récoltes) habituelles de la procédure en laboratoire. La bibliographie, ainsi que mes propres observations avancent deux mécanismes homéostatiques. Le cannibalisme aide ¿̀ régulariser la population d' $A$. tonsa quand la nourriture devient rare par suite de la haute densité des populations. La proportion des femelles adultes augmente durant les densités basses des populations d'A. tonsa. La proportion sexuelle génésique de ces populations était de 1:1. L'augmentation proportionnelle des femelles paraisse provenir de mâles génotypiques changeant en femelles phénotypiques au cours de leur croissance. Cette proportion plus élevée des femelles augmente le taux de la reproduction quand les populations étaient peu denses.
\end{abstract}

\section{INTRODUCTION}

Life is precarious for calanoid copepods in most natural populations. The herbivorous and omnivorous calanoids are commonly subjected to intense predation. Some populations are known to replace their biomass every 2 days or less (HeINLE 1966, 1969b). Predation and the mechanisms that have been evolved to compensate for it are among the most important aspects of the ecology of these organisms. The only laboratory study of exploited populations of micro-crustacea that I am aware of is the work reviewed by SLOBOdKIN (1960) and the study by Marshall (1967) of irradiated Daphnia.

I cultured two species of calanoid copepods, Acartia tonsa (DANA) and Eurytemora affinis (POPPE), in the laboratory to verify high rates of production of wild populations and to obtain data on life histories.

* Natural Resources Institute Contribution No. 394. This research was partially supported by funds of the Office of Water Resources Research, United States Department of the Interior, through the University of Maryland Water Resources Research Center, Project A-002 Md. Some of this material was submitted in partial fulfillment of the requirements for the $\mathrm{Ph} . \mathrm{D}$. degree at the University of Maryland, College Park. 


\section{MATERIAL AND METHODS}

Copepods were grown in the laboratory from December 1965 to February 1968. Two years were spent developing techniques of culture (HEINLE 1969a) and quantirative data on population dynamics were obtained only from May 1967 to February 1968. There were 13 culture attempts that were partially successful (copepods were maintained for more than one generation under a particular set of conditions). Cultures were harvested by stirring them vigorously in an attempt to achieve homogeneity, and pouring out half the volume at desired intervals. The harvested half was concentrated in a Clarke-Bumpus net cup with a No. 62 Nitex net window, preserved in 10 percent formalin, and counted as yield.

Of the 13 cultures, 8 were able to withstand modest predation rates while the remaining 5 cultures declined when subjected to similar harvests. Of the eight, two suffered simultaneous mass mortalities, apparently from extrinsic causes, and one was cultured at a low temperature which slowed the accumulation of data; 5 cultures remained and provided useful data.

The intervals at which the cultures were harvested were selected in advance as follows. An interval was chosen that previous experience indicated would allow the population to replace itself easily. The first harvest schedule was followed for 60 to 70 days. The interval between harvests was then decreased by 0.5 day (at $20^{\circ} \mathrm{C}$ or above) or by 1.0 day (at $15^{\circ} \mathrm{C}$ or below). Harvesting continued at the new rate for 60 to 70 days, and the process was repeated until a schedule was attained that resulted in depletion of the population.

The turnover time of the population that resulted from harvesting was calculated from the interval between harvests by:

$$
\text { Turnover time }=\text { antilog } \frac{\begin{array}{c}
\text { [1n days between harvests }+1 \mathrm{n}(2 \times \\
\text { days between harvests })]
\end{array}}{2}
$$

The formula above was based on the assumption that population growth was exponential between harvests. It was equivalent to calculating turnover time by:

$$
\text { Turnover time }=\frac{\text { (geometric mean of population size) }}{\text { (daily yield) }}
$$

Death rates $(D)$ were then calculated by:

$$
\mathrm{D}=\frac{1}{\text { Turnover time }}
$$

Birth rates were calculated directly from the numbers of copepods and eggs in the samples and from the times required for the eggs to hatch. Birth rate was expressed as births per copepod-day.

\section{RESULTS}

The numbers of copepods in the five cultures fluctuated (Figs 1 and 2). One culture of Acartia tonsa (not shown in Fig. 1) went to extinction at the first exposure to a 3.5 day interval between harvests. There were at least two types of fluctuations, based on their approximate period. Major changes in total density of copepods 
(measured as yield) occurred, with a several-fold difference between maxima and minima, and with an interval of 60 to 80 days between peaks. These major fluctuations of density were roughly in synchrony in all the cultures, and may have had a common cause. There was no apparent relationship between the quantity of algae that was fed during a given period and the density of copepods in the cultures. Records of the

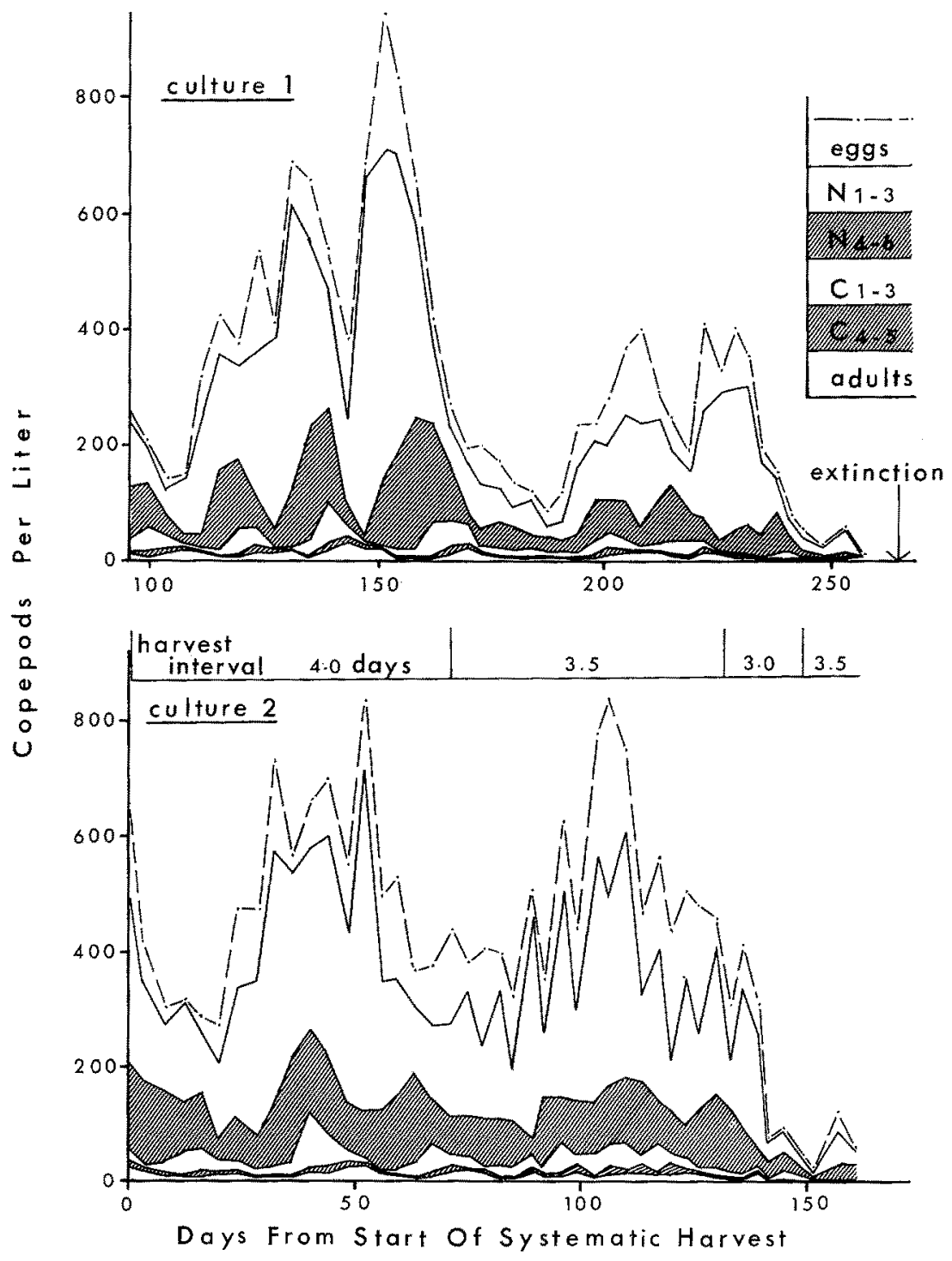

Fig. 1: Yield (copepods per liter) of two cultures of Acartia tonsa. The time scales are adjusted so that chronological time coincides for the two cultures. Culture 1 was grown in bay water $(12 \mathrm{ppt})$ and Culture 2 was grown in "Instant $\operatorname{Ocean}^{3 *}(12 \mathrm{ppt})$. N $1-3=$ nauplius $1-3$ etc. Harvest interval indicates the number of days between harvests 
optical density of the algae, the measure of quantity of food, were not kept during the early part of the experiments, however, and a causal relationship may have been missed. There were lesser fluctuations in some cultures, often of particular age groups, that appeared to result from a combination of the feeding and harvest schedules. The period of these oscillations equalled ( 7 days) $x$ (interval between harvests). As the

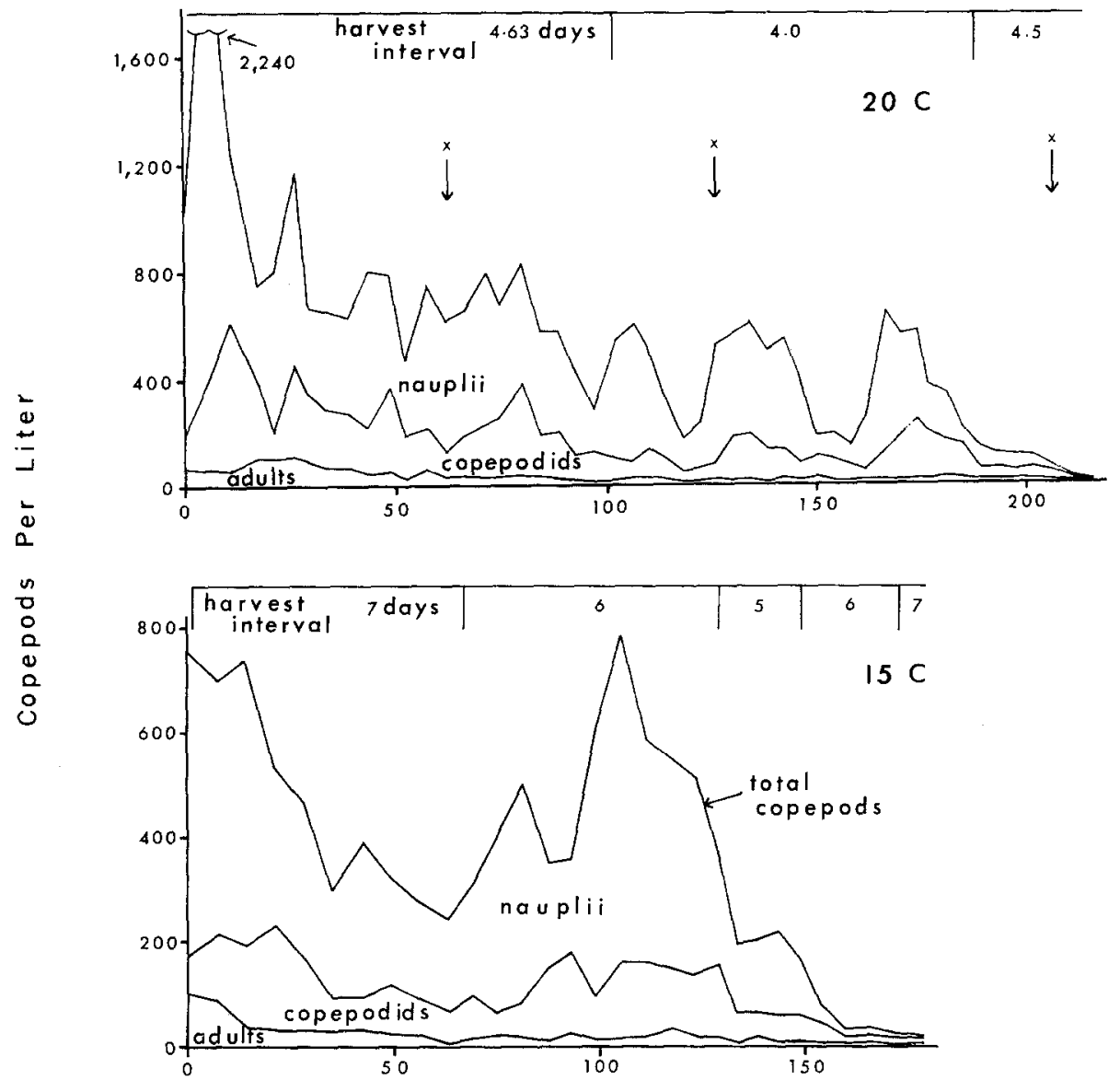

Fig. 2: Yield (copepods per liter) of cultures of Eurytemora affinis at $20^{\circ}$ and $15^{\circ} \mathrm{C}$. Day 0 of the culture at $15^{\circ} \mathrm{C}$ corresponds chronologically to day 130 of the culture at $20^{\circ} \mathrm{C}$, and to day 8 of Acartia tonsa culture 2 (Fig. 1). The X's with arrows indicate when the culture at $20^{\circ} \mathrm{C}$ was transferred to clean flasks (see HeInLe 1969a)

cultures were fed three times a week, there was one day each week (Sunday) when the copepods had less food than on any other day. The copepods were usually able to clear the food from the cultures in two days. Because of the oscillations in numbers of copepods, the population statistics that were based on averages should be viewed as suggestive estimates rather than precise data.

The times required for development of eggs of Eurytemora affinis were: 12.5 days 
at $5^{\circ} \mathrm{C}, 4.1$ days at $10^{\circ} \mathrm{C}, 1.7$ days at $15^{\circ} \mathrm{C}, 1.5$ days at $20^{\circ} \mathrm{C}$, and 1.0 day at $25^{\circ} \mathrm{C}$. The time required for development of eggs of Arcartia tonsa was 0.90 days at $20^{\circ} \mathrm{C}$.

The birth rates (b) that were observed were usually much higher than were necessary to replace the individuals that were harvested (Figs 3 and 4). The populations of Arcatia tonsa had a higher percentage of nauplii and a lower percentage of copepodites than did the populations of Eurytemora affinis. The populations of both species
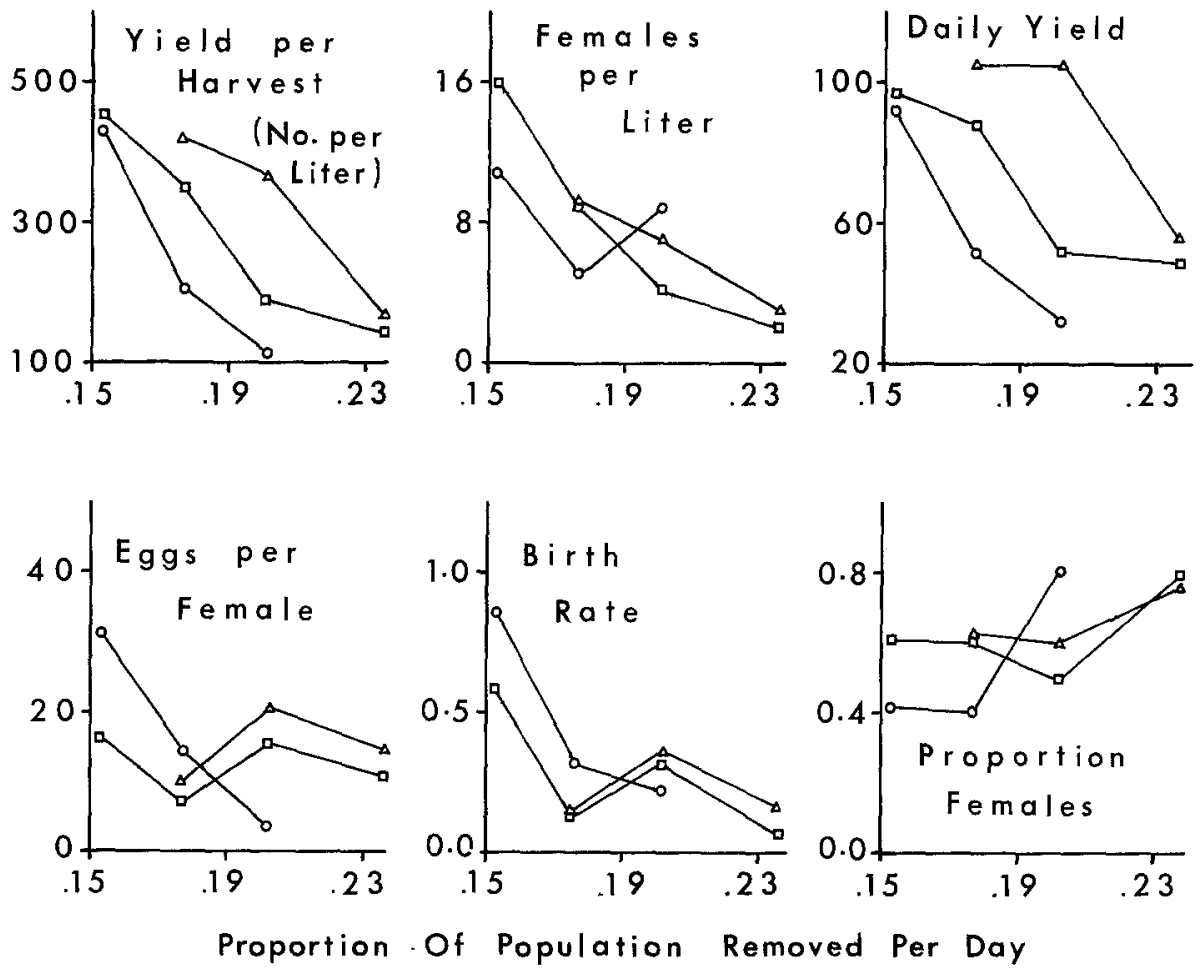

Fig. 3: Population statistics of Acartia tonsa. The last point on the right for each culture represents a rate of harvest that led to depletion of the population. Squares: culture 1, triangles: culture 2, circles: culture 3. The captions of the individual sub-figures indicate the ordinates

had more nauplii and fewer adults than would be expected if the age distribution resulted only from the imposed death rates (D) and deaths of adults at an advanced age. If $\mathrm{D}$ were the only significant source of deaths, the age distribution would be a negative exponential, be $e^{-D r}$, where $e$ is the base of the natural logarithms. The age distributions of the cultures of $E$. affinis were closely approximated by be-bt Some of the observed age structures of $A$. tonsa were verified by analog simulation of extra mortality of 20 to $60 \%$ per day of the first nine instars (HeInLE 1969b). Among the thousands of $A$. tonsa examined from the laboratory cultures, no more than a few dozen were obviously dead at the time they were preserved. Partially decomposed 
copepods, especially adults, were common in the samples from the cultures of $E$. affinis, but by no means abundant. It seems quite possible that cannibalism occurred, particularly in the cultures of $A$. tonsa.

Cultures 1 and 2 of Arcatia tonsa were similar in most respects, while culture 3 was usually different (Fig. 3). Culture 3 was driven to extinction by a more modest preda-

$15 \mathrm{C}$

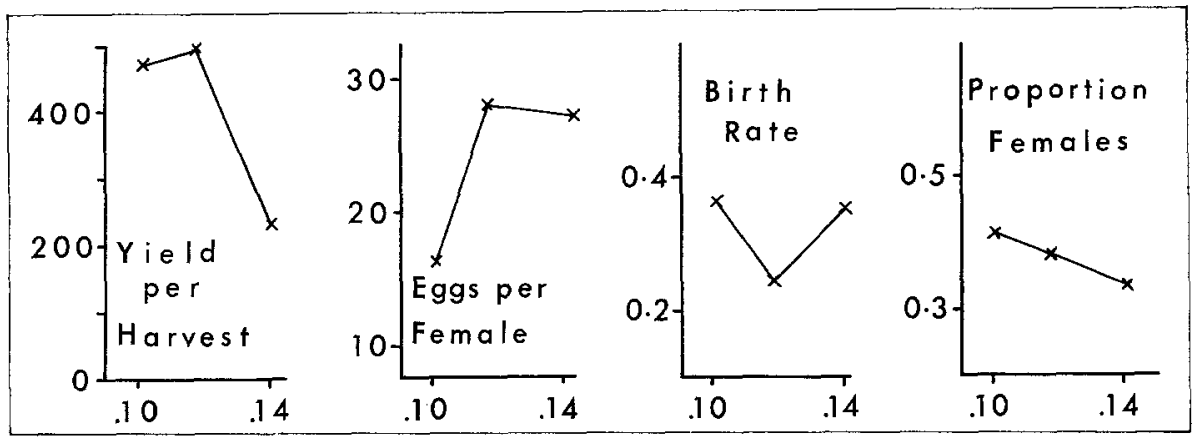

$20 \mathrm{C}$
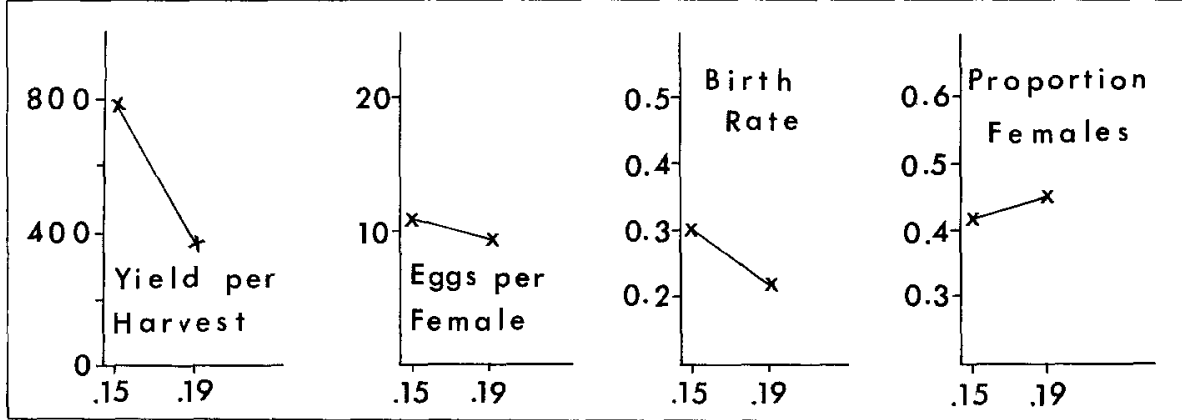

Proportion Of Population Removed Per Day

Fig. 4: Population statistics of Eurytemora affinis at $15^{\circ}$ and $20^{\circ} \mathrm{C}$. The figure layout is the same as in Figure 3

tion rate $(0.202$ per day) than cultures 1 and $2(0.236$ per day). If the plots of culture 3 were moved to the right until the terminal points (representing the rate of harvest that led to depletion) for all three coincided, agreement of the three would be improved in yield per harvest, daily yield, and the proportion of the adults that were females.

Several trends were apparent from the statistics of the cultures of Arcatia tonsa. The yield per harvest, and therefore the mean population density, decreased with increasing rates of predation. The daily yield also decreased with increasing rates of harvest, but not as much as did the yield per harvest. The numbers of eggs per female and the birth rate were relatively constant in cultures 1 and 2 , and decreased in cul- 
ture 3, with increased predation. Birth rates were less than rates of harvest when predation exceeded the capacity for replacement. The birth rates and numbers of eggs per female in the exploited populations of $A$. tonsa (Fig. 3) may not represent the true capacity of this species. Seven female $A$. tonsa, of unknown age, that were isolated

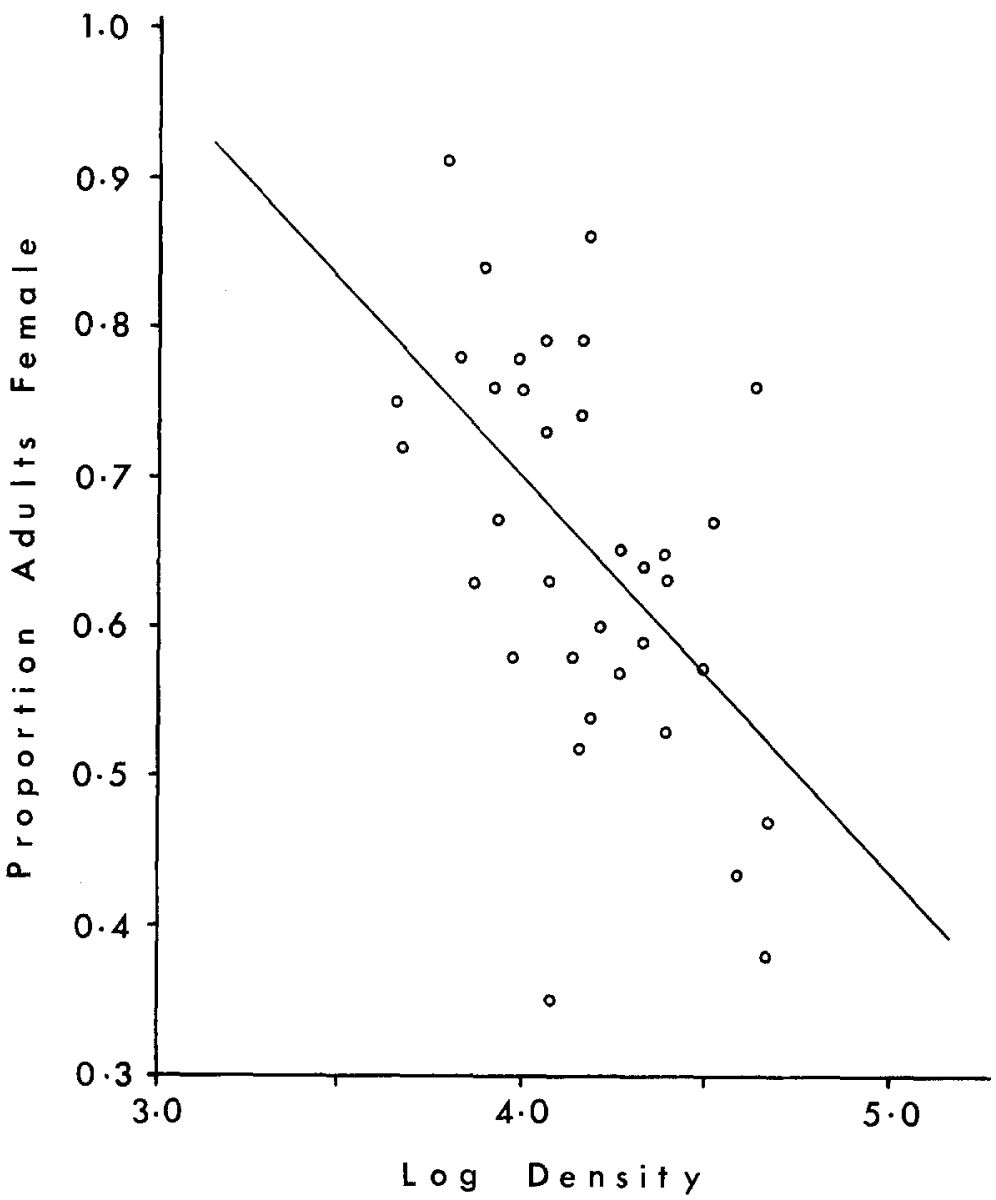

Fig. 5: Proportion of adult female Acartia tonsa versus logarithm of copepodite plus adult density (numbers $\mathrm{m}^{-3}$ ) in samples taken from the Patuxent estuary during June through September. Consult text for the regression equation

and used as a source of eggs for the measurement of hatching time, laid between 8 and 112 eggs each during the first day (mean $=50$ eggs per female). Five of the females were kept alive for three additional days and laid 18 to 40 eggs each the second day (mean $=31$ ), 18 to 34 eggs each the third day (mean $=27$ ), and 5 to 36 eggs each on the fourth day (mean $=22$ ). The female that laid 112 eggs during the first day of the experiment was accidentally killed at the end of the day. The lowest number of eggs on each day was always laid by the same female. 
In the cultures of Eurytemora affinis the yield per harvest decreased only at the predation rates that exceeded the capacity of the populations (Fig. 4). As E. affinis grew more slowly than Arcatia tonsa, the rates of harvest were lower. The numbers of eggs per female rose at the intermediate predation rates and stayed high during excessive predation. Birth rates were variable and showed no clear trend but were near the rates of harvest at the highest exploitation rate.

The sex ratios of the adult copepods changed with the rate of harvest (Figs 3 and 4). In the cultures of Arcatia tonsa the proportion of females increased at the highest rates of predation. (The yield per harvest, which reflected population size, at the highest rates of predation was actually an average value for the rapidly declining population.) In the cultures of Eurytemora affinis, the proportion of the adults that were females was always below 0.5 . As a result of the changes in sex ratio, the cause for failure of the cultures of $A$. tonsa was the eventual total absence of males. The females then laid sterile eggs. [Data were plotted (Fig. 3) only until sterile eggs first appeared in the yield.] One culture (number 2) was saved by the addition of two adult males, after the females had been laying sterile eggs for two weeks. It thus appeared that the sex ratio of $A$. tonsa was altered in response to low densities of copepods, or to excessive rates of predation.

To test the hypothesis that the sex ratio of Arcatia tonsa varied with population density, a regression analysis was performed on the data obtained on sex ratios of adults from a wild population in the Patuxent estuary, Maryland. Only data from samples obtained from June through September were used (months when temperatures, and therefore growth rates, were high), to assure that there was little time lag between cause and effect in determining sex. Preliminary plots of the data suggested that a semilog transformation was appropriate. Regression of proportion of the adults that were female versus the logarithm of the density of copepods was tested. Five separate regressions were done using the densities of different developmental stages of $A$. tonsa: (1) all stages except eggs, (2) adults plus copepodites, (3) adults only, (4) copepodites only, and (5) nauplii only. All slopes were significantly different from zero (1\%) and all correlation coefficients were significant $(1 \%)$. The highest correlation coefficient, steepest slope, and largest values of $t$ were observed in the regression of the proportion of the female adults vs. $\log$ density of copepodids plus adults. The regression equation was: Proportion females $=1.754-0.264$ (log density of adults plus copepodites); $\mathrm{n}=35$, variance of $\mathrm{Y}$ on $\mathrm{X}=0.36, \mathrm{R}=-0.545, \mathrm{t}(\mathrm{R})=4.46$, $\mathrm{t}(\mathrm{b})=-3.72$. Density was expressed as numbers per cubic meter (Fig. 5).

Adult Arcatia tonsa from experiments on growth rate (Hernle 1966, 1969b) provided a source of information on genetic sex ratios. In those experiments eggs from a wild population were placed in 1-liter containers and grown to various stages of development. Nearly total survival was observed and early deaths of males did not occur. The sex ratio of the adults in the experiments on growth rate that were done during June through September was 1:1 (Table 1). The only experiment in which the sex ratio varied significantly from 1:1 was performed in September and incubated at $12^{\circ} \mathrm{C}$, a temperature $7^{\circ} \mathrm{C}$ lower than that in the estuary when the eggs were collected. The density of $A$. tonsa in the experiments on growth rates that were tested ranged from 14 to 338 per liter (Table 1). The regression equation (Fig. 5) based on 
wild copepods predicted a sex ratio of $1: 1$ at a density of 56 copepodites plus adults per liter, and a higher proportion of females at lower densities. While the genetic sex ratio of $A$. tonsa was $1: 1$ (Table 1 ), the phenotypic expression of sex was under the influence of population density (Figs 3 and 5).

Table 1

Sex ratios of Acartia tonsa from experiments on rates of growth (Heinle 1966, 1969b). Only adult $A$. tonsa were sexed, while the numbers per liter were based on all developmental stages. Sample volumes ranged from 2 to 28 liters

\begin{tabular}{|c|c|c|c|c|c|c|}
\hline $\begin{array}{c}\text { Date } \\
\text { samples } \\
\text { were taken }\end{array}$ & $\begin{array}{l}\text { No. } \\
\text { males }\end{array}$ & $\begin{array}{l}\text { No. } \\
\text { females }\end{array}$ & $\begin{array}{l}\text { Proportion } \\
\text { females }\end{array}$ & $\begin{array}{c}\text { Chi } \\
\text { square }\end{array}$ & $\begin{array}{l}\text { A. tonsa } \\
\text { per liter }\end{array}$ & $\begin{array}{c}\text { Other } \\
\text { copepods } \\
\text { per liter }\end{array}$ \\
\hline 29 June 64 & 84 & 92 & 0.52 & 0.360 & 62 & 94 \\
\hline 9 July 64 & 82 & 82 & 0.50 & 0.006 & 48 & 41 \\
\hline 9 July 64 & 65 & 66 & 0.50 & 0.008 & 76 & 63 \\
\hline 9 July 64 & 87 & 85 & 0.49 & 0.023 & 53 & 53 \\
\hline 18 July 64 & 109 & 103 & 0.49 & 0.170 & 338 & 34 \\
\hline 29 July 64 & 685 & 666 & 0.49 & 0.267 & 60 & 9 \\
\hline 29 July 64 & 173 & 180 & 0.51 & 0.139 & 125 & 113 \\
\hline 29 July 64 & 41 & 43 & 0.51 & 0.048 & 79 & 105 \\
\hline 6 Aug. 64 & 123 & 133 & 0.52 & 0.391 & 34 & 59 \\
\hline 6 Aug. 64 & 167 & 165 & 0.50 & 0.012 & 49 & 55 \\
\hline 6 Aug. 64 & 177 & 181 & 0.51 & 0.045 & 75 & 43 \\
\hline 13 Aug. 64 & 88 & 90 & 0.51 & 0.022 & 78 & 57 \\
\hline 9 Sept. 64 & 19 & 20 & 0.51 & 0.026 & 14 & 27 \\
\hline 9 Sept. 64 & 41 & 49 & 0.54 & 0.711 & 28 & 31 \\
\hline 9 Sept. 64 & 38 & 64 & 0.63 & $6.63^{* *}$ & 51 & 110 \\
\hline 17 Sept. 64 & 78 & 81 & 0.51 & 0.057 & 27 & 21 \\
\hline 3 June 65 & 243 & 228 & 0.48 & 0.478 & 118 & 79 \\
\hline 6 July 66 & 97 & 111 & 0.53 & 0.942 & 53 & 91 \\
\hline 8 Šept. 66 & 207 & 191 & 0.48 & 0.643 & 69 & 44 \\
\hline 23 Sept. 66 & 29 & 31 & 0.52 & 0.066 & 44 & 25 \\
\hline 18 Aug. 67 & 59 & 44 & 0.43 & 2.18 & 50 & 332 \\
\hline
\end{tabular}

More data are needed to evaluate the factors regulating the sex ratios of Eurytemora affinis. In the laboratory cultures, there were always more males than females (Fig. 4). In the samples from the estuary, male $E$. affinis always predominated, and there were often 10 males per female.

The changes in sex ratios of Arcatia tonsa and Eurytemora affinis in response to population density appear to be homeostatic mechanisms that are related to a basic difference in the biology of the two species. Female E. affinis required copulation before each clutch of eggs. In the absence of males, eggs were not laid. Furthermore, late copulation resulted in an egg sac being dropped before the eggs hatched, so that the next clutch could be laid on schedule. (In the presence of males, a new clutch of eggs was always ready to be laid when the egg sac of the preceding clutch was dropped or broken by the hatching of the eggs.) By contrast, A. tonsa females that had been fertilized were observed to lay eggs continuously for at least four days in the absence of males. These females laid from 49 to 133 eggs each during that time. For $A$. tonsa, the increased proportion of females at low population density was probably a mechanism for increasing reproductive rates. For $E$. affinis, the increased proportion of males appears to be a means of assuring copulation when population densities are low. 


\section{DISCUSSION}

The fluctuations in population density observed were similar to those described by Marshall (1967) for his populations of Daphnia. Such fluctuations probably reflect the discontinuity of events in laboratory cultures. The decrease in standing crop observed with increased rates of exploitation was also similar to the findings of Marshall. Other statistics, such as yield and birth rate differed. Marshall found that yield was a bell-shaped function of rate of exploitation and that birth rate increased with increased predation, in contrast to my findings (Figs 3 and 4). All my data may have been taken at rates of exploitation that were higher than that providing the maximum sustainable yield. Another possibility is that the population dynamics of the copepods that I studied differed because of homeostatic mechanisms.

Conover (1956) suggests that Arcatia tonsa might be cannibalistic. ANraku \& OMori (1963) found that adult $A$. tonsa consumed both plant and animal (Artemia nauplii) material without preference, when a mixture was available. Analog simulation of the age structures of exploited populations of $A$. tonsa that I observed suggested that there were mortalities among juveniles in laboratory populations in excess of the rate of harvest. The magnitude of the extra mortality (20 to 60\% per day of the first nine stages), and the absence of decomposing copepods in the yield, indicated that cannibalism occurred. Like many other calanoids $A$. tonsa does not filter continuously (ANRAKU 1964, CoNOVER 1964), and when food was abundant feeding was intermittent. With non-selective feeding, the amount of animal material eaten would depend on the relative concentrations of plant and animal material. The densities of adult copepods in my laboratory cultures, and in the experiments of ANRAKU \& OMORI (1963), were higher than those generally encountered in wild populations. It seems likely that cannibalism acted as a mechanism for regulating populations of $A$. tonsa when food was scarce and densities of populations were high.

The second homeostatic mechanism, alteration of sex ratios, occurred in both the wild and laboratory populations of Arcatia tonsa and perhaps of Eurytemora affinis. There appear to be at least two ways that sex ratios of copepods can be altered. One, described by BATTAGLIA $(1958,1959,1963)$, involved changes in the genetic ratios of a harpactacoid copepod in response to the density of populations and to temperature and salinity. BATTAGLIA suggested that changes in sex ratio were caused by a polygenic effect, with an increase in females when heterozygosity increased, and an increase in males with increased homozygosity. Low population densities, and subsequent inbreeding and selective inbreeding in the laboratory led to increased homozygosity and a high proportion of males. Natural populations were generally outbreeding, and females predominated except during periods of low population density. While differences in survival of the genotypes were not observed, differences in sexual activity were: homozygous males and heterozygous females being more active (BATTAGLIA 1963).

The preponderance of males in laboratory cultures of Eurytemora affinis (Fig. 4) and the linear relationship to rate of harvest that was observed in one culture suggest that the sex ratio of this species was under environmental control. My data were inadequate to suggest the mechanism for control of sex ratios of E. affinis, but the 
predominance of males was similar to the observations of BATTAGLiA $(1958,1959$, 1963).

The preponderance of females in natural populations of calanoid copepods has been observed so frequently that it is a generalization. Bogorov (1939) concluded that the high proportion of females usually resulted from rapid death of males after copulation, a phenomenon that definitely occurs in some species (CAmpbell 1934). WOODMANSEE (1958) suggested early death of males as the cause of the preponderance of females in a population of Arcatia tonsa, based on the conclusions of CAmpbell (1934) and Bogorov (1939). Mednikov (1961) first suggested the possibility of an ecological cause for the scarcity of males. He concluded that a "trophic factor" was involved, and that the low proportion of males was an adaptation for increasing fecundity when food was scarce. BAYLY (1965) found a high proportion of females at low population densities among three sympatric species of copepods that altered seasonally in abundance. He felt that a predominance of females was a general adaptation for survival at low population densities, rather than a response to low food supply. The basis for that conclusion was the fact that only the species that were scarce at a particular time had a low proportion of males. TImms (1968) found a high proportion of females in populations of calanoid copepods living in reservoirs with high rates of renewal of water. Timms suggested an indirect effect by the mechanisms proposed by Mednikov (1961) and BAYLY (1965), since standing crops of phytoplankton and copepods were lower in lakes with high rates of renewal of water (RAvERA \& ToNOLLI 1956).

Most authors have not discussed sex ratios of immature copepods. However, Marshall (1949) found that even when females predominated in the adult stage, the sex ratios were nearly even among copepodites. CONOvER (1965a) had difficulty sexing fifth copepodid stages of Calanus byperboreus (KRøYER), using subtle morphological differences (shape of the urosome). Dissection of the gonads was used to check sex ratios predicted from the proportions of the urosome. Predictions based on the shape of the urosome indicated more males than were found upon dissection of the gonads. Copepodites of C. byperboreus that moulted into adults in the laboratory had a higher proportion of males than was observed in natural populations of that species. Conover (1965b) observed one copepod that was an intersex.

My data indicate that while the sex ratios of adult Arcatia tonsa were related to the density of the population (Figs 3 and 5), the genetic sex ratio was unity (Table 1). There was no indication of early death of males. It appears that a portion of the genetic males became phenotypic females during the course of their growth, in response to low population densities. They were probably functional females since the numbers of eggs per female were not appreciably lower in cultures 1 and 2 when the proportion of females increased (Fig. 3). Sterile eggs did not appear in the cultures until phenotypic males were absent. The mechanism for alteration of sex was not indicated by my data, but the semi-logarithmic relationship of the proportion of females to density (Fig. 5) suggested a simple response to the concentration of copepods in the water. Either the copepods themselves through contact or proximity, or a metabolite, may have affected the expression of sex. As BAYLY (1965) found for the three species that he studied, the proportions of female $A$. tonsa (Fig. 5 and Table 1) were not appar- 
ently influenced by the densities of other species of copepods, suggesting that simple products of metabolism (e. g. $\mathrm{CO}_{2}$ and $\mathrm{NH}_{4}$ ) were not involved.

The male phenotype was converted to the female phenotype in an amphipod following surgical manipulation that caused supression of the androgenic hormone (Charniaux-Cotton 1965). While an androgenic gland has not been demonstrated in copepods, neurosecretory cells have been (CARLISLE \& PITMAN 1961); further studies of sex ratios of copepods should consider the possibility of hormonal control.

Homeostatic mechanisms and high rates of reproduction allow the two species that I studied to maintain relatively stable populations in the wild (HEINLE 1969b), in spite of intense predation. While the population dynamics of the wild populations were not duplicated in the laboratory, they were approximated. A laboratory situation that more closely resembled the conditions of the wild populations would add much to our understanding of these important organisms.

\section{SUMMARY}

1. Population densities of calanoid copepods fluctuated in cultures subjected to exploitation rates of from 10 to $24 \%$ of the populations per day. The fluctuations were probably caused by the discontinuous events (feeding and harvesting) that were inherent in the laboratory procedure.

2. Birth rates in the cultures were much higher than were necessary to replace the individuals removed by predation except at rates of exploitation that depleted the populations.

3. Cannibalism probably occurred in the cultures of Acartia tonsa.

4. Population density decreased with increasing rates of predation in cultures of Arcatia tonsa. The same statistic decreased only with excessive predation in cultures of Eurytemora affinis.

5. Sex ratios changed with increasing predation. The proportion of adult Arcatia tonsa that were females increased at the highest rates of exploitation. The proportion of female adults in a wild population was inversely proportional to the logarithm of population density. The genetic sex ratio in the same population was unity. There was no indication of early death of males. It thus appeared that genotypic males became phenotypic females during the course of their growth. Males predominated in both wild and laboratory populations of Eurytemora affinis.

6. Changes in sex ratio of the two species appear to be homeostatic mechanisms. Reproductive rates of Arcatia tonsa were increased at low population densities by the higher proportion of females. The increased proportion of males in populations of Eurytemora affinis may be a means for assuring copulation at low population densities.

Acknowledgements. I would like to thank Mr. E. Dunnington and Dr. D. H. HAMILTON for their assistance with the manuscript. 


\section{LITERATURE CITED}

ANRAKU, M., 1964. Some technical problems encountered in quantitative studies of grazing and predation by marine planktonic copepods. J. oceanogr. Soc. Japan 20, 19-29.

- \& OMORI, M., 1963. Preliminary survey of the relationship between the feeding habit and the structure of the mouth-parts of marine copepods. Limnol. Oceanogr. 8, 116-126.

Battaglia, B., 1958. Sex ratio in Tisbe gracilis, a marine copepod. Int. Congr. Zool. 15 (London), Sect. 3, paper 24.

- 1959. Facteur thermique et différenciation saisonnière chez un copépode harpacticoide de la Lagune de Venise. Vie Milieu 10, 1-13.

- 1963. Deviations from panmixia as a consequence of sex determination in the marine copepod, Tisbe reticulata. Int. Conf. Genet. 11 (1), 9-26 (Abstr.).

BayLY, I. A. E., 1965. Ecological studies on the planktonic copepoda of the Brisbane River estuary with special reference to Gladioferens pectinatus (Bradr) (Calanoida). Aust. J. mar. Freshwat. Res, 16, 315-350.

Bogorov, V. G., 1939. Sex ratio in marine copepoda. Dokl. Akad. Nauk SSSR 23, 705-708.

Campbell, M. H., 1934. The life history and post-embryonic development of the copepods, Calanus tonsus (BradY) and Euchaeta japonica (MARUKaWA). J. biol. Bd. Can. 1, 1-65.

Carlisle, D. B. \& Pitman, W. J., 1961. Diapause, neurosecretion, and hormones in copepoda. Nature, Lond. 90 (4778), 827-828.

Charniaux-Cotton, H., 1965. Hormonal control of sex differentiation in invertebrates. In: Organogenesis. Ed. by R. L. DeHaAn \& H. Ursprung. Holt, Reinhart \& Winston, New York, 701-740.

Conover, R. J., 1956. Oceanography of Long Island Sound, 1952-1954. VI. Biology of Acartia clausi and A. tonsa. Bull. Bingham oceanogr. Coll. 15, 156-233.

- 1964. Food relations and nutrition of zooplankton. In: Experimental marine ecology. Proceedings of a Symposium held 1963. Occ. Publ. Narraganser Mar. Lab. 2, 81-89.

- 1965a. Notes on the moulting cycle, development of sexual characters and sex ratio in Calanus byperboreus. Crustaceana 8, 307-320.

- 1965b. An intersex in Calanus byperboreus. Crustaceana 8, 153-158.

Hernle, D. R., 1966. Production of a calanoid copepod, Acartia tonsa, in the Patuxent River estuary. Chesapeake Sci. 7, 59-74.

- 1969a. Culture of calanoid copepods in synthetic sea water. J. Fish. Res. Bd Can. 26, 150-153.

- 1969b. Effects of temperature on the population dynamics of estuarine copepods. Ph. D. Thesis, Univ. of Maryland, College Park, 132 pp.

Marshall, J. S., 1967. Radiation stress in exploited Daphnia populations. Limnol. Oceanogr. 12, 154-158.

Marshall, S. M., 1949. On the biology of small copepods in Loch Striven. J. mar. biol. Ass. U. K. 28, 45-122.

Mednikov, B. M., 1961. On the sex ratio in deep sea calanoida. Crustaceana 3, $105-109$.

Ravera, O. \& Tonolli, V., 1956. Body size and number of eggs in diaptomids, as related to water renewal in mountain lakes. Limnol. Oceanogr. 1, 118-122.

Slobodkin, L. B., 1960. Ecological energy relationships at the population level. Am. Nat. 94, 213-236.

Trmms, B. V., 1968. Comparative species compostion of limnetic planktonic crustacean communities in South-east Queensland, Australia. Hydrobiologia 31, 481--491.

Woodmansee, R. A., 1958. The seasonal distribution of zooplankton off Chicken Key in Biscayne Bay, Florida. Ecology 39, 247-262.

Author's address: Dr. D. R. Heinle

University of Maryland

Natural Resources Institute

Chesapeake Biological Laboratory

Solomons, Md. 20688, USA 